\title{
Absorption Rates of Different Volatile Fatty Acid Mixtures Infused into the Rumen of Young Calves
}

\author{
Taketo OBITsu and Kohzo T ANIGUCHI \\ Faculty of Applied Biological Science, Hiroshima University, \\ Higashihiroshima-shi 724
}

(Received April 21, 1994)

Key words : volatile fatty acids, absorption, rumen, calves

The development of ruminal absorptive capacity for volatile fatty acids (VFA) in young calves partly depends on the facilitation of papillary growth stimulated by VFA produced in the rumen ${ }^{9,14)}$. The promotive effect of VFA on papillary growth is not only dose dependent but also varies with individual fatty acids $^{9}$. Thus, the composition of VFA produced in the rumen may affect the ruminal absorption rate of VFA in young calves via change in ruminal absorptive capacity. The determination of the VFA absorption rate from the rumen requires quantification of the ruminal production rate of VFA. However, accurate measurement of the VFA production rate is difficult under normal feeding conditions $^{15)}$. Application of the intragastric infusion technique ${ }^{6)}$, whereby infusates are exactly controllable, may be useful for measuring the ruminal absorption rate of VFA.

In this study, we compared the VFA absorption rate from the rumen of young calves given high $(42 \mathrm{~mol} / 100 \mathrm{~mol})$ and low $(17 \mathrm{~mol} / 100 \mathrm{~mol})$ propionate VFA mixtures into the rumen by the intragastric infusion technique.

\section{Materials and Methods}

Animals and management: Six male Holstein calves (birth weight $47 \pm 8 \mathrm{~kg}$; mean $\pm S D$ ) born at the experimental farm of Hiroshima University were used. Whole cow's milk (10\% of body weight) was nipple-fed in two equal portions at $09: 00$ and $17: 00$ until 6 or $8 \mathrm{wks}$ of age. Four calves were fitted with a ruminal cannula and an abomasal catheter at $2 \mathrm{wks}$ of age, but two calves were fitted at 5 wks of age. The surgical procedures were the same as those described in a previous study ${ }^{5)}$. Intragastric nutrient infusion started $7 \mathrm{~d}$ after surgery and continued for $43 \mathrm{~d}$.

Intragastric nutrition: The details of infusion procedures for young calves are described elsew here ${ }^{5)}$. In bricf, VF $\Lambda$ mixtures containing major minerals and a bicarbonate buffer solution were infused separately into the rumen : one peristaltic pump was used for the VFA infusion and two pumps were used for the buffer infusion. The infused VFA mixture

若龄子牛の第一胃内へ注入した組成の異なる揮発性脂肪酸混合物の吸収速度 : 小㹂剛人・谷口幸三（広島大学生物 生産学部, 東広島市 724) 
contained $0.6-1.1$ mol total VFA/l (with $2.2 \mathrm{~g}$ $\mathrm{CaCO}_{3} / l, 0.6 \mathrm{~g} \mathrm{MgCl}_{2} \cdot 6 \mathrm{H}_{2} \mathrm{O} / l$ and $2.0 \mathrm{~g} \mathrm{Ca}\left(\mathrm{H}_{2} \mathrm{PO}_{4}\right)_{2}$ $\left.\cdot \mathrm{H}_{2} \mathrm{O} / l\right)$. The infused buffer solution contained $0.174 \mathrm{~mol} \quad \mathrm{NaHCO}_{3} / l$ and $0.076 \mathrm{~mol}$ $\mathrm{KHCO}_{3} / l$. The maximum volume of ruminal infusate (VFA mixture plus buffer solution) was approximately $1.0 \mathrm{l} / \mathrm{BW}^{0.75}$. A casein solution containing $33 \mathrm{~g}$ casein $/ l, 1.7 \mathrm{~g} \mathrm{Na}_{2} \mathrm{CO}_{3} / l$ and vitamin mixture was infused continuously into the abomasum, but the suspension of trace minerals was infused rapidly into the abomasum once a day. No solid diet was offered from birth until the end of the experiment. As substitute roughage to maintain ruminal motility, polypropylene ropes $(3 \mathrm{~m})$ were placed in the rumen on the first day of infusion.

During the first $14 \mathrm{~d}$ of infusion (adaptation period), the infusate supply was gradually increased with a gradual decrease in the milk supply to reach the planned level of 1.3 times the maintenance requirement of metabolizable energy ${ }^{10)}\left(570 \mathrm{~kJ} / \mathrm{BW}^{0.75}\right)$ at the end of the adaptation period. During this period, the amount of infused VFA was increased at the rate of approximately $20 \mathrm{mmol} / \mathrm{BW}^{0.75}$ per day to reach the level of the maintenance requirement ${ }^{10)}(440$ $\mathrm{kJ} / \mathrm{BW}^{0.75}$ ). Similarly, the amount of infused casein was also increased at the rate of approximately $60 \mathrm{mg} / \mathrm{BW}^{0.75}$ per day to reach $1.0 \mathrm{~g}$ nitrogen/BW ${ }^{0.75}\left(130 \mathrm{~kJ} / \mathrm{BW}^{0.75}\right)$. After the adaptation period, calves were nourished by the infusates only. The total energy supply from infusates during 15 to $43 \mathrm{~d}$ of the infusion (measurement period) was planned to be kept at 1.3 times the maintenance requirement. The amount of infused bicarbonate was planned to be approximately $0.4 \mathrm{~mol}$ bicarbonate/mol VFA. However, the actual amounts of VFA and bicarbonate were adjusted according to the ruminal $\mathrm{pH}$ and osmotic pressure, to be kept above 6.0 and below $280 \mathrm{mOsm} / l$, respectively.

Treatments: Three calves were intraruminally infused with a high-propionic acid mixture (mixture HP) containing acetic, propi- onic and butyric acids in the proportions 48,42 and $10 \mathrm{~mol} / 100 \mathrm{~mol}$, respectively, throughout the whole infusion period. The other three calves were intraruminally infused with a lowpropionic acid mixture (mixture LP) containing acetic, propionic and butyric acids in the proportions 76,14 and $10 \mathrm{~mol} / 100 \mathrm{~mol}$, respectively. These high- and low-propionic acid mixtures were close to the maximum and minimum compositions of propionic acid found in young calves $\left.{ }^{13}{ }^{17}\right)$. Because of the isocaloric infusion of total VFA for the both treatments, planned daily amounts of infused total VFA after $15 \mathrm{~d}$ were 340 and $400 \mathrm{mmol} / \mathrm{BW}^{0.75}$ for $\mathrm{HP}$ and $L P$, respectively.

Measurements : Ruminal $\mathrm{pH}$ and osmotic pressure were measured every day at 17:00 during the whole infusion period as described previously ${ }^{5}$.

The volume and fractional outflow rate of ruminal liquor were estimated every $1-2 \mathrm{wks}$ during the measurement period. A pulse dose of $10 \mathrm{~g}$ polyethylene glycol (PEG; average molecular weight $3000 ; 20 \%(\mathrm{~W} / \mathrm{V})$ aqueous solution) was injected through the ruminal cannula at $10: 00$, and then ruminal liquor (every $50 \mathrm{~m} l$ ) was collected at $0.5,1,2,4,6,10,14,18,22,26$ and $30 \mathrm{~h}$ after administration of PEG. Ruminal PEG concentration was measured by turbidimetry ${ }^{11)}$ for all samples, but the ruminal concentration of $\mathrm{VFA}^{16)}, \mathrm{pH}^{53}$ and osmotic pressure $^{5)}$ were measured at 6,14 and $22 \mathrm{~h}$ only. The volume and fractional outflow rate of ruminal liquor were estimated by linear regression of the natural logarithm of ruminal PEG concentration on time after the dose of $\mathrm{PEG}^{3.7)}$.

Because VFA infused into the rumen is absorbed via the rumen wall and (or) flows out to the post-rumen, the relationship of the fractional absorption rate of total VFA from the rumen $\left(\mathrm{k}_{\Lambda} ; \% / \mathrm{h}\right)$, the fractional outflow rate of total VFA from the rumen $\left(\mathrm{k}_{\mathrm{o}} ; \% / \mathrm{h}\right)$, the ruminal concentration of total $\mathrm{VFA}(\mathrm{C} ; \mathrm{mol} / \mathrm{l})$ and the volume of ruminal liquor $(\mathrm{V} ; l)$ to the infusion rate of total VFA $(\mathrm{I} ; \mathrm{mol} / \mathrm{h})$ is defined 


\section{ObItsu and TANIGUCHI}

by the following equation ;

$$
\mathrm{I}=\left(\mathbf{k}_{\mathrm{A}}+\mathrm{k}_{0}\right) \times \mathrm{C} \times \mathrm{V} / 100 .
$$

Thus, the fractional absorption rate of total VFA $\left(\mathbf{k}_{\mathrm{A}}\right)$ is estimated by the following equation ;

$$
\left.\mathrm{k}_{\mathrm{A}}=[100 \times \mathrm{I} /(\mathrm{C} \times \mathrm{V})]-\mathrm{k}_{\mathrm{o}} . \quad \text { (eq. } 2\right)
$$

In this equation, the fractional outflow rate of VFA was assumed to be equal to the fractional outflow rate of ruminal liquor. In addition, ruminal VFA concentration was assumed to be maintained in a steady state within the measuremant day. In our other experiment with a calf nourished by intragastric infusion, the coefficient variation for the diurnal VFA concentration in the rumen, measured at every $4 \mathrm{~h}$, was only $2.0 \%$ (unpublished date). Thus, the average value of ruminal concentrations of total VFA at 6,14 and $22 \mathrm{~h}$ after the dose of PEG was used in the calculation. The total VFA absorbed from the rumen $(\mathrm{mol} / \mathrm{h})$ was estimated as $\mathrm{k}_{\mathrm{A}} \times \mathrm{C} \times \mathrm{V}$. The proportion of the amount of VFA absorbed to that infused on the measurement day was also calculated.

The treatment means for fractional absorption rates during 15 to $28 \mathrm{~d}$ (period I) and 29 to $43 \mathrm{~d}$ (period II) were calculated. The treat ment means on the ruminal infusate amount and ruminal liquor characteristics on the day of VFA absorption measurement were also calculated as described above. Because the VFA absorption rate for the one calf infused with the mixture HP could not be measured during period $I$, the treatment means for calves in fused with the mixture HP during this period were calculated as $n=2$. The significance of difference $(\mathrm{P}<0.05)$ in these results between calves infused with different VFA mixtures in period I and period II was analyzed by the $\mathrm{t}-$ test $^{12\rangle}$.

\section{Results and Discussion}

Nutritional state: The means of daily energy supply from milk plus infusates through the adaptation period were $753 \pm 88$ $\mathrm{kJ} / \mathrm{BW}^{0.75}$ for calves infused with mixture HP and $718 \pm 150 \mathrm{~kJ} / \mathrm{BW}^{0.75}$ for calves infused with mixture LP (mean $\pm S D, n=3$ ). Total nitrogen supply from milk plus casein during this period was $1.1 \pm 0.1 \mathrm{~g} / \mathrm{BW}^{0.75}$ for both groups (mean $\pm \mathrm{SD}, \mathrm{n}=3$ ). Thus the energy and nitrogen intake of calves in both groups exceeded their maintenance requirements ${ }^{1,10)}$ throughout the adaptation period.

The amount of VFA infused during the measurement period was approximately $80-$ $95 \%$ and $75-85 \%$ of the planned level for HP and $L P$, respectively, due to the prevention of low ruminal liquor $\mathrm{pH}$. The mean daily amounts of total VFA infused (mmol/BW ${ }^{0.75}$; mean $\pm \mathrm{SD}$ ) during periods $\mathrm{I}$ and $I$ were $278 \pm$ $47(n=3)$ and $329 \pm 29(n=2)$ for HP and $302 \pm 55$ $(\mathrm{n}=3)$ and $332 \pm 52(\mathrm{n}=3)$ for LP, respectively.

The ruminal $\mathrm{pH}$ and osmotic pressure measured at 17:00 every day for each calf during the whole infusion period ranged from 5.2 to 7.0 and from 260 to $330 \mathrm{mOsm} / l$, respectively. These figures did not deviate from the range of normal feeding ${ }^{2)}$.

Ruminal VFA absorption: The data for the fractional absorption rate of total VFA are shown in Tabel 1 together with the infusion rate of ruminal infusate and ruminal liquor characteristics on the day of VFA absorption measurement. The fractional absorption rate of total VFA from the rumen did not differ $(\mathrm{P}>$ $0.05)$ between the treatments in period $I$, but was greater $(P<0.05)$ for $H P$ calves than for $L P$ calves in period $\mathbb{I I}$. The fractional absorption rate of total VFA for HP calves, in contrast with that for LP calves, increased rapidly with the advancement of the infusion period. In addition, regression analysis of the fractional absorption rate of total VFA throughout the whole mcasurement period on the day after infusion started gave regression coefficients of 2.07 ( $\mathrm{SE} ; 0.35, \mathrm{P}<0.01$ ) for $\mathrm{HP}$ calves and 0.82 ( $\mathrm{SE} ; 0.37, \mathrm{P}<0.10$ ) for LP calves. This implies that the incremental increase in VFA absorption rate with infusion day advancement was greater $(\mathrm{P}<0.05)$ for HP than for LP. The daily 
Table 1. Daily amounts of ruminal infusates, characteristics of ruminal liquor and fractional absorption rate of total VFA from the rumen of calves infused with different VFA mixtures'

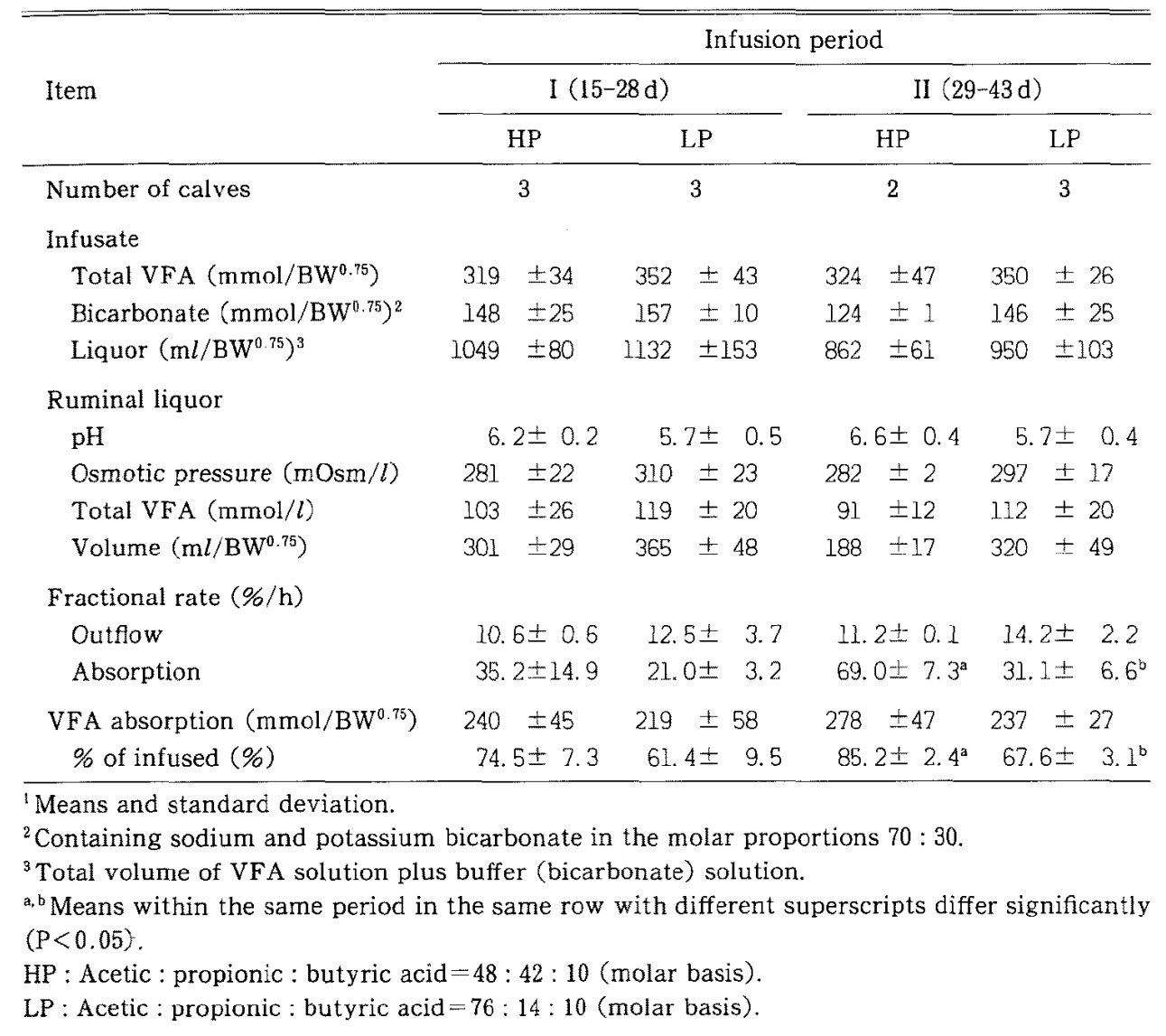

amount of total VFA absorbed from the rumen did not differ $(\mathrm{P}>0.05)$ between the treatments in either period I or period II. However, the proportion of total VFA absorbed from the rumen to the total VFA infused was greater $(\mathrm{P}$ $<0.05)$ for HP calves than for LP calves in period II.

Early findings have indicated that the promotional effect of propionate on papillary growth is greater than that of acetate ${ }^{97}$, and that the development of ruminal absorptive capacity through papillary growth affects the VFA absorption rate ${ }^{14)}$. In this study, therefore, the high-propionic acid mixture possibly facilitated ruminal absorptive capacity via promoted papillary growth.
The characteristics of ruminal liquor, for example $\mathrm{pH}^{4.14)}$, osmorality ${ }^{8)}$ and ruminal liquor volume ${ }^{4)}$, also affect the ruminal absorption rate of VFA. In this study, unfortunately, ruminal $\mathrm{pH}$ and ruminal liquor volume tended to differ $(\mathrm{P}<0.20$ and $\mathrm{P}<0.10$, respectively) between HP calves and LP calves in period II (Table 1).

Thus, the influence of these variables, besides VFA composition, on VFA absorption may not be disregarded. Further research is needed to clarify the relationship between the composition of VFA infused into the rumen and the development of the absorptive capacity for VFA in young calves. 


\section{Acknowledgments}

This study was supported by a Grant-in-Aid for Scientific Research (No. 02856071) from the Ministry of Education, Science and Culture, Japan.

\section{References}

1) Agricultural Research Council. The Nutrient Requirements of Ruminant Livestock. 121-181. Commonwealth Agricultural Bureaux. England. 1980.

2) Church, D.C., Digestive Physiology and Nutrition of Ruminants vol.1. Digestive Physiology. 2nd ed. 166-173. O \& B Books. Oregon. 1976.

3) CZERKAWSKI, J.W., An Introduction to Rumen Studies. 36-38. Pergamon Press. Oxford. 1986.

4) Dijkstra, J., H. Boer, J.V. Bruchem, M. BRUining and S. TAMMINGA, Absorption of volatile fatty acids from the rumen of lactating dairy cows as influenced by volatile fatty acids concentration, $\mathrm{pH}$ and rumen liquid volume. Br. J. Nutr., 69 : 385-396. 1993.

5) Obitsu. T., K. Taniguchl and Y. Yamatani, Application of a method of intragastric nutrient infusion to young calves. Anim. Sci. Technol. (Jpn.), 64: 732-740. 1993. (in Japanease)

6) Ørskov, E.R., D.A. Grubb, G. Wenham and W. CORRIGAL, The sustenance of growing and fattening ruminants by intragastric infusion of volatile fatty acid and protein. Br. J. Nutr., 41 : 553-559. 1979.

7) ØrsKov, E.R., N.A. MAcLEOD and D.J. KYLE, Flow of nitrogen from the rumen and abomasum in cattle and sheep given protein-free nutrients by intragastric infusion. Br. J. Nutr., 56: 241-248. 1986.

8) Osho, S. and I. TAHATA, Absorption of dissociated volatile fatty acids through the rumen wall of sheep. Can. J. Anim. Sci,, 64
(Suppl.) : 167-168. 1984.

9) SANDER, F.G., R.G. WARnER, H.M. HARrison and J.K. LoosLI, The stimulatory effect of sodium butyrate and sodium propionate on the development of rumen mucosa in the young calf. J. Dairy Sci., 42 : 1600-1605. 1959.

10) Sekine, J., T. Morooka, M. Okubo and $Y$. ASAHIDA, The estimation of metabolizable energy requirement for maintenance and growth of growing calves weaned at six weeks of age. Jpn. J. Zootech. Sci., 58 : 266-272. 1987.

11) SмIтH, R.H., The development and function of the rumen in milk-fed calves. J. Agric. Sci., $52: 72-78.1959$.

12) Steel, R.G.D. and J.H Torrie, Principles and Procedures of Statistics. 2nd ed. 86-100. McGraw--Hill Publishing Company. New York. 1980.

13) Stobo, I.J.F., J.H.B. Roy and H.J. GAston, Rumen development in the calf. 2. The effect of diets containing different proportions of concentrates to hay on digestive efficiency. $\mathrm{Br} . \mathrm{J}$. Nutr., 20 : 189-215, 1966.

14) Sutron, J.D., A.D. MCGilliard and N.L. JACOBSON, Functional development of rumen. I. Absorptive ability. J. Dairy Sci., 46 : 426-436. 1963.

15) Sutron, J.D., Digestion and absorption of energy substrates in lactating cow. J. Dairy Sci., 68 : 3376-3393. 1985.

16) Taniguchi, K., M. Hanada, T. Obitsu and $Y$. YAMATANI, Combinations of different sources of starch and protein : effect on site and extent of carbohydrate digestion in steers. Anim. Sci. and Technol. (Jpn.), 62:699-710. 1991.

17) Williams, P.E. V., G.M. InNes, A. BREWER and J. P. MAGADI, The effect on growth, food intake and rumen volume of including untreated or ammonia-treated barley straw in a complete diet for weaning calves. Anim. Prod., $41: 63-74$. 1985. 